\author{
Marek Zwolankowski \\ Katedra Finansów \\ Uniwersytet Szczeciński
}

\title{
Złożoność globalnego systemu finansowego - nowe wyzwania dla banków centralnych
}

\section{Streszczenie}

Złożoność struktur systemu finansowego postawiła nowe wyzwania przed bankami centralnymi w zakresie szacowania ryzyka systemowego i kształtowania globalnej stabilności finansowej. Złożona i powiązana z niepewnością natura współczesnego kryzysu finansowego ujawniła niedoskonałą wiedzę regulatorów, w tym banków centralnych, na temat związków przyczynowo-skutkowych występujących na globalnych rynkach finansowych. Mówiąc językiem T.S. Kuhna, ekonomiści dobrze identyfikują skutki zdarzeń wywołujących kryzys finansowy, lecz mają trudności z kontekstem uzasadnienia jego przyczyn. Kryzys finansowy jest zatem również kryzysem poznania, czego przykład stanowi fakt, że uczestnicy rynku finansowego mieli ograniczoną zdolność percepcji ryzyka, natomiast instytucje systemu regulacji finansowej napotkały bariery w wywieraniu wpływu na zachowania rynkowe uczestników tego rynku. Przełomem w tym względzie powinno być konsekwentne powierzanie współczesnym bankom centralnym zadań w zakresie nadzoru makroekonomicznego.

Słowa kluczowe: polityka pieniężna, kryzys finansowy, regulacja makroostrożnościowa, złożoność.

\section{Wprowadzenie}

Środowisko współczesnych banków centralnych zdaniem A. Orphanidesa i V. Wielanda [2013, s. 167-169] cechuje złożoność wynikająca z niepewności 
(w oryginale „splotu niepewności”), utrudniającą diagnozę stanu gospodarki i pomiar jej dynamiki. Dyskusja o niepewności, zwłaszcza w kontekście reguł dla polityki pieniężnej, nie jest nowa. Utrwaliło się w jej efekcie rozróżnianie niepewności modeli i niepewności warunków oraz szerokie akceptowanie tezy o „obciążonych niepewnością" wyborach modeli, prognozach i parametrach [Blinder 2001, s. 25-29]. Obiektywne w tym kontekście ograniczenia w formułowaniu efektywnej strategii polityki pieniężnej i jej systemu operacyjnego zwiększył kryzys finansowy. Złożoność struktur systemu finansowego postawiła nowe wyzwania przed bankami centralnymi w zakresie szacowania ryzyka systemowego i kształtowania globalnej stabilności finansowej. Celem artykułu jest identyfikacja tych wyzwań, a kluczowym przesłaniem - akcentowanie wymogu globalnego zaangażowania banków centralnych w nadzór makroostrożnościowy.

\section{Natura i źródła złożoności globalnego systemu finansowego}

Złożoność systemów finansowych uznaje się często za uogólnioną przyczynę globalnej niestabilności finansowej. W poszukiwaniu istoty współczesnej gospodarki i źródeł jej dynamiki warto kierować się myślą E.S. Pheplsa [2009, s. xiiixvii], by skonfrontować szczególne właściwości gospodarki tradycyjnej, której istotą jest rutyna, z gospodarką zmodernizowaną. Ta ostatnia otwiera drzwi do nowych aktywności, sprawia, że główną funkcją współczesnych gospodarek jest generowanie zmian, a pochodną tej funkcji - wiecznie niedoskonała wiedza co do ich natury. Użyteczne w rozwinięciu takiego opisu są dwa pojęcia - wzrostu i rozwoju.

W dziedzinie analizy systemowej przyjęło się następujące rozróżnienie tych dwóch pojęć-kluczy: wzrastać oznacza zwiększać swoje rozmiary przez asymilację i przyrost materii, zaś rozwijać się oznacza rozszerzać możliwości, dochodzić do pełniejszego, większego bądź lepszego stanu [Meadows, Meadows i Randers 1955, s. xxiii]. W tym kontekście można postawić następującą tezę dotyczącą niekontrolowanej dynamiki współczesnego systemu: instytucje i rynki finansowe rosną (zwiększają swoje rozmiary), równocześnie mogą się one jednak nie rozwijać, gdyż nie doskonalą się pod względem sposobu realizacji funkcji. Z powyższą tezą koresponduje badanie [Arcand, Berkes i Panizza 2012, s. 1-4 i 23] dotyczące wpływu rozmiarów systemów finansowych na globalne rozprzestrzenianie się kryzysu finansowego. Jego autorzy oszacowali próg rozmiarów systemu finansowego, powyżej którego dalszy rozwój nie przekłada się na wzrost produkcji w sferze realnej. Takim optimum jest granica relacji kredytów dla sektora prywatnego do PKB na poziomie 110\%. W 2006 r. 15 krajów przekroczyło ten próg. 
Konkluzja tego badania, aczkolwiek nie podana w sposób niepodważalny (Too much finance?), dobrze wpisuje się w treść fundamentalnej dyskusji o tempie przemian w światowym systemie finansowym. Dostarcza ono kolejnego dowodu na tendencję odrywania się jego struktur od realnej sfery gospodarki. W innym studium porównawczym [von Treeck, Hein i Duenhaupt 2007, s. 1, 5-7] przeanalizowano linię rozwojową systemów finansowych i gospodarek USA oraz Niemiec. Podkreślono - tuż po równoległym załamaniu się amerykańskiego rynku nieruchomości i rynku pieniężnego, jak wielkim zagrożeniom podlegają gospodarki, w których modele wzrostu są nadmiernie skoncentrowane na wzroście rynku finansowego. Współczesny system finansowy charakteryzuje złożoność struktur i tak niekontrolowana dynamika, że w rezultacie jest on obiektywnie narażony na utratę stabilności. W związku z tym analiza współczesnego systemu finansowego jest wielowątkowa, budzi kontrowersje i nadal wymaga stawiania pytań o fundamentalnym znaczeniu.

Taki charakter pytań wpisuje się w postulat metodologiczny T.S. Kuhna [2001, s. 10, 32-35, 146-147], utożsamiany z pojęciem paradygmatu i z zaleceniem wysokiej dyscypliny badawczej (nakazującym uwzględniać w badaniu różnicę pomiędzy „kontekstem odkrycia” i „kontekstem uzasadnienia”). Jednak badania oparte na paradygmatach, czyli powszechnie uznawanych, modelowych problemach i rozwiązaniach, nie zwalniają od poszukiwania odchyleń od przewidywań teoretycznych, czyli anomalii. Współczesny kryzys finansowy, będąc splotem nadzwyczajnych zdarzeń, objawił się również jako kryzys w myśli ekonomicznej. „Mówiąc w skrócie - mamy dobry warsztat pozwalający relatywnie łatwo odpowiadać na pytania o «skutki przyczyn», a nie o «przyczyny skutków»" [Belka 2013, s. 19]. Mówiąc językiem T.S. Kuhna, ekonomiści dobrze odkrywają skutki zdarzeń wywołujących kryzys finansowy, lecz mają trudności z kontekstem uzasadnienia jego przyczyn. Świadomość tych ograniczeń nie przekreśla jednak próby ułożenia łańcucha przyczyn i skutków globalnego kryzysu finansowego (rys. 1).

Zjawisko określone jako great moderation (wielkie umiarkowanie) traktujemy w naszym podejściu jako wczesną przyczynę wysokiej dynamiki gospodarki światowej przed sierpniem 2007 r. (początki kryzysu finansowego). Kwantyfikację tej tendencji, ze znacznym zmniejszeniem zmienności inflacji i PKB w gospodarce Stanów Zjednoczonych, ilustruje tabela 1.

Efekt „wielkiego umiarkowania” dotyczył nie tylko gospodarki amerykańskiej, gdyż miał wymiar ogólnoświatowy. Splot czterech czynników: deregulacji, globalizacji, innowacji finansowych i publicznego zrozumienia kosztu inflacji ukształtował w gospodarce światowej specjalną formę ,konkurencji między walutami”. Przyczyniła się ona do poprawy efektywności polityki monetarnej banków centralnych oraz uzyskania efektu kontrolowanej niskiej inflacji w wymiarze międzynarodowym. W takich warunkach zawiązał się trend fundamentalny, 
a przyjazne środowisko monetarne (niskie i stabilne stopy procentowe) zaczęło sprzyjać agresywnym strategiom inwestycyjnym na rynku finansowym. Można przyjąć, że wyłoniło się w tamtym okresie pierwsze ogniwo w łańcuchu zjawisk przyczynowo-skutkowych pod nazwą „ryzyko systemowe”. Taki wniosek wynika z silnego przeświadczenia o „(...) wzajemnej zależności czynników psychologicznych i fundamentalnych w napędzaniu cen aktywów i ryzyka" [Frydman i Goldberg 2013, s. 11].

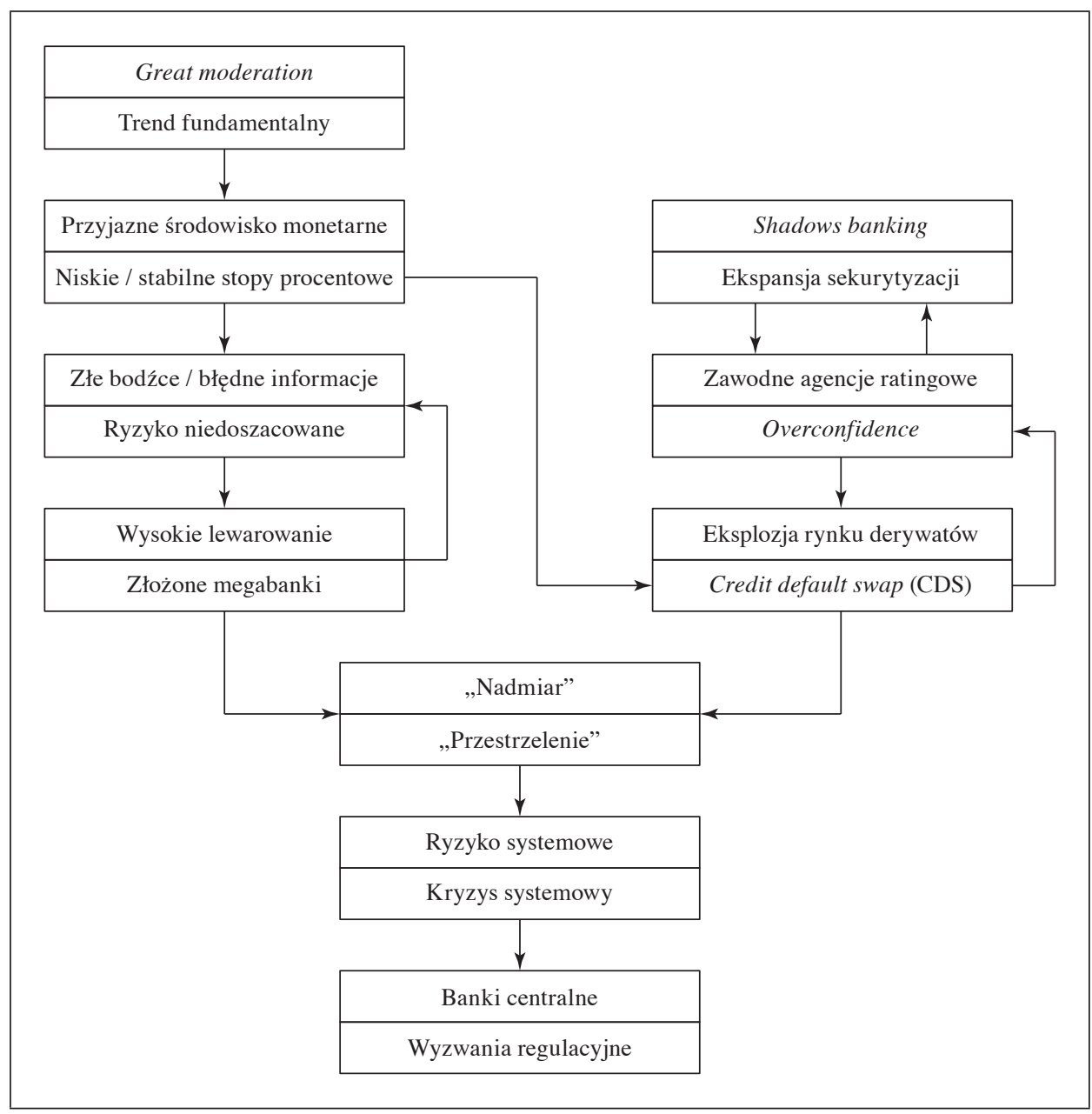

Rys. 1. Źródła i aspekty dynamiki współczesnego systemu finansowego Źródło: opracowanie własne. 
Tabela 1. Zjawisko great moderation w USA i jego charakterystyki ilościowe

\begin{tabular}{|l|c|c|c|}
\hline \multirow{2}{*}{$\begin{array}{c}\text { Kluczowe charakte- } \\
\text { rystyki makroekono- } \\
\text { miczne }\end{array}$} & $\begin{array}{c}\text { Zmienność mierzona odchyleniem standardo- } \\
\text { wym (przemnożonym przez 100) }\end{array}$ & $\begin{array}{c}\text { Redukcja zmienności } \\
(\%)\end{array}$ \\
\cline { 2 - 3 } & $1965-1983$ & $1984-2006$ & 55 \\
\hline PKB & 1,126 & 0,508 & 60 \\
\hline Inflacja & 0,609 & 0,244 & 31 \\
\hline Stopa procentowa & 0,847 & 0,583 & \\
\hline
\end{tabular}

Źródło: [Pescatori 2008, s. 3].

Spójny z takim stanowiskiem jest pogląd J.B. Taylora [2010, s. 23-27], według którego luźna polityka pieniężna banku centralnego i wywołany w jej konsekwencji nadmiar natury czysto pieniężnej jest przyczyną następujących po sobie faz boomu i załamania. Faza boomu dotarła nie tylko na rynek kredytów hipotecznych i nieruchomości. Równolegle odnotowano ekspansję w innym segmencie amerykańskiego systemu finansowego: strukturalną (wzrost systemu shadows banking) oraz procesową (ekspansję sekurytyzacji). W tym miejscu można przywołać niektóre założenia metodyczne przyjmowane w badaniu dynamiki złożonych systemów. Współbieżność zjawisk, równoległość bodźców i sygnałów oraz przejawianie się sprzężeń zwrotnych jest dowodem złożoności systemu [Holland 2006, s. 1-2]. Niskie i stabilne stopy procentowe sprzyjały rozwojowi rynku transakcji sekurytyzacyjnych w dwojaki sposób. Po pierwsze, podaż kredytów hipotecznych otwierała przestrzeń do ich sekurytyzacji, a po drugie, niskie stopy procentowe sprzyjały popytowi na bardziej ryzykowne sekurytyzowane papiery wartościowe (ze stopami zwrotu powyżej rentowności rynku obligacji).

Ponieważ instytucje shadows banking kreują płynność finansową, ale pozostają poza systemem regulacji bankowej, wyłania się następujący wniosek: aktywność tych podmiotów wymyka się spod regulacyjnych wpływów banku centralnego. Wyjątkowo trafne wydaje się więc określenie tych instytucji pośrednictwa finansowego przyjęte przez S. George [2011, s. 61]; ,widmowy system bankowy”. Ponadto banki chętnie udzielają kredytów, które dają się łatwo sekurytyzować; chcą czerpać zyski z samego pośrednictwa finansowego, a nie z cierpliwego inwestowania [Duffie 2008, s. 16-17]. Takie zjawisko dobrze ilustruje wcześniej podnoszoną sprzeczność pomiędzy wzrostem i rozwojem; shadows banking rośnie, lecz z punktu widzenia interesu społecznego się nie rozwija. Źródłem dynamiki tego segmentu systemu finansowego stały się również błędy agencji ratingowych, które skutkowały obniżeniem wartości informacyjnej ratingu kredytowego [McClintock Ekins i Calabria 2012, s. 1-2] (z negatywnymi skutkami dla rynku - niedoszacowane ryzyko inwestycyjne i nadmierna pewność siebie inwestorów finansowych). 
Osobne miejsce w tej diagnozie należy poświęcić dużym bankom, zaliczanym obecnie do banków ważnych systemowo (z dużym potencjałem systemowej destrukcji). W tabeli 2 zamieszczono dane dotyczące relacji aktywów trzech (top 3) oraz dziesięciu (top 10) największych banków do globalnego PKB.

Tabela 2. Aktywa największych globalnych banków (w \%) w porównaniu z globalnym PKB (w wybranych latach okresu 1974-2013).

\begin{tabular}{|c|c|c|}
\hline Rok & Top 3 & Top 10 \\
\hline 1974 & 3 & 8 \\
\hline 1988 & 6 & 15 \\
\hline 1997 & 6 & 16 \\
\hline 2007 & 17 & 43 \\
\hline 2013 & 11 & 33 \\
\hline
\end{tabular}

Źródło: opracowanie własne na postawie [Tarullo 2014, s. 21].

Te duże i złożone pod wieloma względami - organizacyjnie, biznesowo i geograficznie - instytucje stosowały wysoką dźwignię finansową, bo koszt pozyskania długu był niski i stabilny. Wykładnikiem swoistej siły banków ważnych systemowo jest również zdolność do opierania się wpływom regulacyjnym banków centralnych. Po pierwsze, w mechanizmie transmisji monetarnej tak duże banki mogą w mniejszym stopniu i ze znacznym opóźnieniem czasowym przenosić impulsy monetarne banków centralnych. Po drugie, duże globalne banki dopuściły się procederu manipulowania jednym z kluczowych benchmarków rynku finansowego, czyli stawką Libor. Zagrożenia megabanków dla stabilności systemowej można wyprowadzić na postawie prawidłowości dużych i złożonych systemów [Rickards 2012, s. 176]. Wzrost rozmiarów takiego systemu pociąga za sobą wykładniczy wzrost ilości energii potrzebnej do jego funkcjonowania. Ponadto złożone systemy są podatne na załamania. Akceptując słuszność tego wywodu, należy stwierdzić, że załamanie się rynku pieniężnego i rynku kapitałowego musiało oznaczać, że megabanki nie będą zdolne „odtwarzać energii” niezbędnej do ich funkcjonowania; ani w postaci płynności finansowej, ani w postaci dodatkowego kapitału własnego. Klamrą spinającą całość tych powiązań jest konkluzja o stanie współczesnego systemu finansowego, który doświadczył skutków nadmiaru monetarnego i „przestrzelenia” (w takim znaczeniu, jakie nadano temu terminowi w raportach Klubu Rzymskiego; ,przestrzelenie” oznacza niezamierzone przekroczenie granic wzrostu). 


\section{Wyzwania regulacyjne dla banków centralnych}

Regulacje finansowe projektowano zbyt często w celu zwalczania wcześniejszego kryzysu finansowego. Regulatorzy nie nadążali za dynamiką rynku finansowego [Dewatripont, Rochet i Tirole 2010, s. 8]. W przypadku funkcji regulacyjnych banków centralnych jedną z przyczyn tego swoistego opóźnienia był ich globalny sukces w stabilizowaniu cen i wartości pieniądza. Z drugiej strony przedkryzysowa dynamika zmian strukturalnych i procesowych na rynkach finansowych dawała asumpt do poszukiwania nowego paradygmatu ekonomiki monetarnej. Zakwestionowano tradycyjne podejście do ekonomiki monetarnej silnie zakorzenione w transakcyjnym popycie na pieniądz i wręcz postawiono tezę o ,poważnej rysie" na tradycyjnej teorii polityki monetarnej [Stiglitz i Greenwald 2003, s. 2, 203-213]. Autorzy argumentowali, że w obszarze oddziaływań regulacyjnych polityka monetarna i polityka regulacji finansowej są ze sobą powiązane, lecz mają inne domeny: odpowiednio makro- i mikroekonomiczną. Rozwinięcie tego podejścia, z uwzględnieniem złożonej natury współczesnego kryzysu finansowego, przedstawiono na rys. 2.

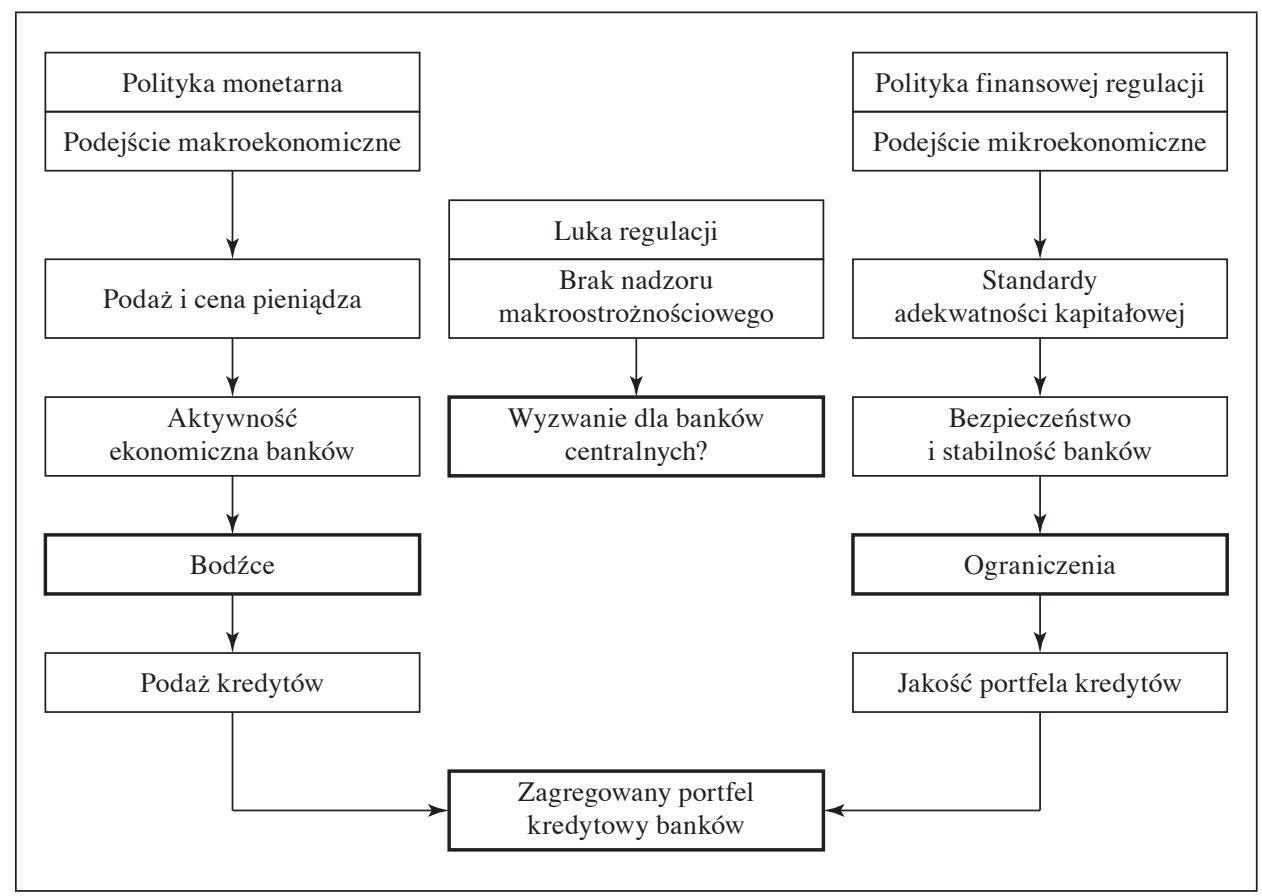

Rys. 2. Stary paradygmat regulowania banków

Źródło: opracowanie własne. 
Obydwie dziedziny polityki mają nie tylko inne domeny, lecz różnią się zasadniczo logiką wpływów regulacyjnych. Polityka monetarna operuje bodźcami i tylko pośrednio kształtuje aktywność ekonomiczną banków. Polityka finansowej regulacji (de facto nadzór bankowy) tworzy ograniczenia i ma zdolność bezpośredniego oddziaływania na bezpieczeństwo i stabilność banków. Ujawnia się więc w sposób niepodważalny luka regulacji - brak nadzoru makroostrożnościowego. Jak wolno sądzić, taką lukę mogą zamknąć w sposób skuteczny tylko banki centralne, czyniąc regulację makroekonomiczną systemem spójnym i kompletnym. W tym świetle przełomem powinno być przyjęte przez Radę UE rozporządzenie powierzające Europejskiemu Bankowi Centralnemu (EBC) szczególne zadania związane z nadzorem ostrożnościowym nad instytucjami kredytowymi. Komentatorzy zakładają [Merler i Wolff 2013, s. 2-4], że nadzór EBC nad dużymi bankami zredukuje dwa źródła niepewności zagrażające systemowej niestabilności: niepewność co do jakości aktywów banków oraz niepewność co do reguł rekapitalizacji i restrukturyzacji banków oraz stosowania reżimu ich uporządkowanej upadłości.

Nie zmienia to jednak faktu, że współczesne gospodarki cechuje niestabilność strukturalna i „(...) że uczestnicy rynku i ekonomiści mają niedoskonałą wiedzę na temat mechanizmów przyczynowo-skutkowych leżących u podstaw zachowań rynku" [Frydman i Goldberg 2009, s. 7]. W konsekwencji banki centralne mogą mieć obiektywne trudności związane z wczesnym rozpoznaniu regularności bądź anomalii na rynkach finansowych, z predykcją, a zatem z trafnym wyborem nastawienia w ramach strategii regulacyjnych. Spójne z tą konstatacją są spostrzeżenia C.E.V. Borio [2007, s. 2-11] dotyczące przemian we współczesnych systemach finansowych i obejmujące dwie ich składowe: zmianę i stałość. Syntezę tego, co ulega zmianie, i tego, co trwa we współczesnych systemach finansowych, ilustruje tabela 3 .

Tabela 3. Zmiany i stałe w systemie finansowym

\begin{tabular}{|l|l|}
\hline \multicolumn{1}{|c|}{ Zmiany w systemie finansowym } & \multicolumn{1}{c|}{ Stałe w systemie finansowym } \\
\hline Atomizacja ryzyka & Problem asymetrii informacji \\
\hline Urynkowienie finansów & $\begin{array}{l}\text { Silne dodatnie sprzężenie zwrotne pomiędzy } \\
\text { monetarną a realną sferą gospodarki }\end{array}$ \\
\hline Nowe konfigurowanie graczy & Ograniczona zdolność percepcji ryzyka \\
\hline Globalizacja finansów & $\begin{array}{l}\text { Ograniczenia regulatorów finansowych } \\
\text { w wywieraniu wpływu na zachowania rynkowe }\end{array}$ \\
\hline $\begin{array}{l}\text { Transfer ryzyka do sektora gospodarstw } \\
\text { domowych }\end{array}$ & \\
\hline
\end{tabular}

Źródło: opracowanie własne na podstawie [Borio 2007, s. 2-5, 8-9]. 
Z perspektywy autora opracowania kluczowe są dwa wnioski dotyczące ograniczeń w percepcji ryzyka oraz ograniczeń regulatorów w wywieraniu wpływu na zachowania rynkowe. Należy podkreślić, że zostały one umieszczone w zbiorze stałych właściwości współczesnego systemu finansowego.

W wyniku kryzysu finansowego zostały zerwane również pewne regularne więzi pomiędzy segmentami rynku finansowego. Ten ostatni wątek warto rozwinąć w świetle tezy A. Estrelli [2001, s. 214] głoszącej, że drogi pomiędzy bankiem centralnym a realną sferą gospodarki „krzyżują się na rynkach finansowych". Bank centralny, stabilizując pieniądz, działa w środowisku rynku pieniężnego i zakłada efektywną transmisję impulsów monetarnych do rynku obligacji. W obecnych warunkach nie funkcjonują już zależności zaobserwowane przez J.J. Murphy'ego [1998, s. 41, 51], a oznaczające, że: wszystkie stopy poruszają się zwykle w tym samy kierunku oraz że punkty zwrotne występują na rynku obligacji na ogół wcześniej niż na rynku akcji.

Na rys. 3 zaprezentowano zmiany szerokiego rynku akcji (indeks S\&P 500) na tle zmian rentowności amerykańskich 10-letnich obligacji skarbowych w USA w latach 1999-2014. Historycznie, a zarazem konwencjonalnie ujmując, wzrostowi cen akcji towarzyszy spadek cen obligacji (czyli wzrost ich rentowności). W praktyce korelacja akcje-obligacje jest trudna do niezawodnej estymacji i podlega drastycznym zmianom w reakcji na cztery zmienne makroekonomiczne: realną stopę procentową, inflację, bezrobocie i wzrost gospodarczy [The Stock-bond... 2013, s. 1-3]. Powtarzalną współzależność rynku akcji i rynku obligacji zniekształciła niekonwencjonalna polityka pieniężna Systemu Rezerwy Federalnej (Fed). Warunki obydwu rynków zaczął kształtować napływ płynności w efekcie skrajnie akomodacyjnej polityki pieniężnej Fed. Druga runda „poluzowania ilościowego" (QE2), polegająca na bezwarunkowym skupie długoterminowych obligacji skarbowych, rozpoczęła się pod koniec 2010 r. Łatwo zauważyć na rys. 3, że w 2011 r. odnotowano głęboki spadek rentowności 10-letnich obligacji skarbowych USA (aktywność Fed) oraz równoległy wzrost szerokiego indeksu S\&P 500 (aktywność inwestorów prywatnych). Polityka pieniężna, której celem było stworzenie impulsu prowzrostowego, przyczyniła się do wykreowania impulsu do inwestycji spekulacyjnych na rynku akcji. Inwestorzy prywatni mogli mieć pewność, że popyt Fed na rynku obligacji skarbowych będzie podtrzymywał wysoki poziom cen tej klasy aktywów. Niekonwencjonalne działanie banku centralnego w skrajny sposób zaczęło rozstrzygać o wycenie obligacji i szacowaniu ryzyka inwestycyjnego, utrwaliło się środowisko inwestycyjne skłaniające do moralnego hazardu. Ponieważ inwestujący na rynku obligacji antycypują decyzje władzy monetarnej, kluczowe znaczenie dla ich zachowań mają informacje o ewentualnej strategii wyjścia ze QE. Pierwsze sugestie co do ograniczania programu skupu obligacji skarbowych (2013 r.) wywołały reakcję inwestorów - sprzedaż tych aktywów 
(a tym samym wzrost ich rentowności). W komentarzach specjalistów [Feroli i in. 2014, s. 2] pojawiło się nawet skrajnie brzmiące określenie: „atak złości” rynku (market tantrums).

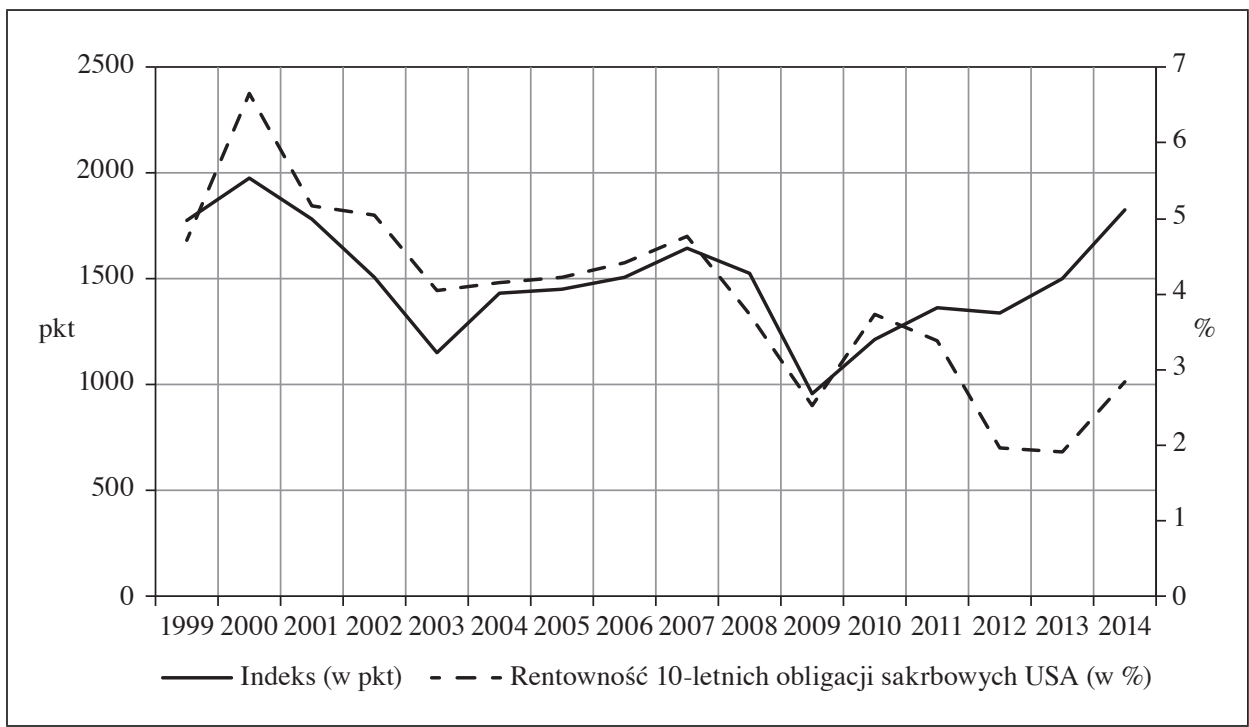

Rys. 3.Zmiany szerokiego rynku akcji (indeks S\&P 500) na tle zmian rentowności amerykańskich 10-letnich obligacji skarbowych w USA w latach 1999-2014 Źródło: opracowanie własne.

Wyjątkową rolę rynku obligacji skarbowych w mechanizmie transmisji motetarnej potwierdza również strategia EBC. Warunki panujące na tym rynku po maju 2010 r., czyli w nowej fazie globalnego kryzysu finansowego, zaburzyły transmisję monetarną w trzech kanałach: cenowym, bilansowym i płynnościowym [Zwolankowski 2012, s. 324-325]. W związku z tym zasady stosowania niekonwencjonalnych narzędzi polityki pieniężnej przez Eurosystem uwzględniały nie tylko tworzenie bodźców dla gospodarki strefy euro. Równą wagę przypisano dwóm innym celom: wsparciu (odtworzeniu) efektywności mechanizmu transmisji monetarnej oraz reaktywowaniu rynku prywatnych inwestycji finansowych.

\section{Podsumowanie}

Jako podsumowanie przedstawionych rozważań można przytoczyć następującą tezę: „Najbardziej obiecującą nową szkołą myślenia jest ta, która zajmuje się rozwijaniem teorii złożoności” [Rickards 2012, s. 175]. Przełamywanie skutków złożo- 
ności współczesnych systemów finansowych jest również wyzwaniem dla banków centralnych. Nie może budzić wątpliwości fakt, że niekonwencjonalna polityka banków centralnych jest eksperymentem w warstwie poznawczej. Tym większe znaczenie dla efektywnego przełamywania skutków kryzysu finansowego należy przypisać strategii komunikacji banków centralnych (forward guidance - informacja wyprzedzająca). Wyzwaniem rangi fundamentalnej jest jednak zaangażowanie się banków centralnych w nadzór makroostrożnościowy. Jest to warunek konieczny przywrócenia stabilności globalnego systemu finansowego - odpornego na wstrząsy i zdolnego do wykonywania funkcji efektywnej alokacji kapitału.

\section{Literatura}

Arcand J.-L., Berkes E., Panizza U. [2012], Too Much Finance? „IMF Working Papers”, nr $12 / 161$.

Belka M. [2013], Dlaczego tylko odkrywać? Lekcje z obecnego kryzysu dla ekonomii i polityki gospodarczej [w:] Ekonomia dla przyszłości. Odkrywać naturę i przyczyny zjawisk gospodarczych, IX Kongres Ekonomistów Polskich, PTE, Warszawa.

Blinder A.S. [2001], Bankowość centralna w teorii i praktyce, CeDeWu, Warszawa.

Borio C.E.V. [2007], Change and Constancy in the Financial System: Implications for Financial Distress and Policy, „BIS Working Papers”, nr 237, October, http://dx.doi. org/10.2139/ssrn.1022874.

Dewatripont M., Rochet J.-Ch., Tirole J. [2010], Balancing the Banks. Global Lessons from the Financial Crisis, Princeton University Press, Princeton-Oxford.

Duffie D. [2008], Innovations in Credit Risk Transfer: Implications for Financial Stability, „BIS Working Papers”, nr 255, Monetary and Economic Department, July, http:// dx.doi.org/10.2139/ssrn.1165484.

Estrella A. [2001], Finanzinnovationen und der monetäre Transmissionsmechanismus, „Berichte und Studien”, nr 3-4.

Feroli M., Kashyap A.K., Schoenholtz K., Shin H.S. [2014], Market Trantums and Monetary Policy, „The Initiative on Global Markets”, nr 101.

Frydman R., Goldberg M.D. [2009], Ekonomia wiedzy niedoskonatej. Kurs walutowy i ryzyko, Wydawnictwo Krytyki Politycznej, Warszawa.

Frydman R., Goldberg M.D. [2013], Mechaniczne rynki i świat realny: wahania cen aktywów, ryzyko i rola państwa, Wydawnictwo Krytyki Politycznej, Warszawa.

George S. [2011], Czyj kryzys, czyja odpowiedź, Instytut Wydawniczy Ksiażka i Prasa, Warszawa.

Holland J.H. [2006], Studying Complex Adaptive Systems, ,Journal of Systems Science and Complexity", vol. 19, nr 1, http://dx.doi.org/10.1007/s11424-006-0001-z.

Kuhn T.S. [2001], Struktura rewolucji naukowych, Wydawnictwo Aletheia, Warszawa.

McClintock Ekins E., Calabria M.A. [2012], Regulation, Market Structure, and Role of the Credit Rating Agencies, ,Policy Analysis”, nr 704, August 1.

Merler S., Wolff G.B. [2013], Ending Uncertainty. Recapitalisation under European Central Bank Supervision, „Breugel Policy Contribution”, nr 18, December. 
Meadows D.H., Meadows D.L., Randers J. [1995], Przekraczanie granic. Globalne załamanie czy bezpieczna przyszłość, Centrum Uniwersalizmu przy Uniwersytecie Warszawskim, Polskie Towarzystwo Współpracy z Klubem Rzymskim, Warszawa.

Murphy J.J. [1998], Międzyrynkowa analiza techniczna. Strategie inwestycyjne na rynkach akcji, obligacji, towarów $i$ walut, WIG Press, Warszawa.

Orphanides A., Wieland V. [2013], Complexity and Monetary Policy, „International Journal of Central Banking", January.

Pescatori A. [2008], The Great Moderation: Good Luck, Good Policy, or Less Oil Dependence, ,Economic Commentary”, March, Federal Reserve Bank of Cleveland.

Phelps E.S. [2009], Przedmowa do: R. Frydman, M.D. Goldberg, Ekonomia wiedzy niedoskonatej. Kurs walutowy i ryzyko, Wydawnictwo Krytyki Politycznej, Warszawa.

Rickards J. [2012], Wojny walutowe. Nadejście kolejnego globalnego kryzysu, Helion, Gliwice.

Stiglitz J.E., Greenwald B. [2003], Towards New Paradigm in Monetary Economics, Cambridge University Press.

Tarullo D.K. [2014], Regulating Large Foreign Banking Organizations [w:] Building the Financial System of the Twenty-first Century, Harvard Law School Symposium, New York, 27 March.

Taylor J.B. [2010], Zrozumieć kryzys finansowy. Przyczyny, skutki, interpretacje, PWE, Warszawa.

Treeck T. von, Hein E., Duenhaupt P. [2007] Finanzsystem und wirtschaftliche Entwicklung: Tendenzen in den USA und in Deutschland aus makrooekonomischer Perspektive, „IMK Studies”, nr 5.

The Stock-bond Correlation [2013], .,Quantitative Research”, PIMCO, November.

Zwolankowski M. [2012], Struktura stóp procentowych banku centralnego a kwestia równowagi monetarnej na rynku pieniężnym [w:] Współczesna bankowość centralna, red. W.L. Jaworski, A. Szelągowska, CeDeWu, Warszawa.

\section{Complexity of the Global Financial System - Challenges Facing Central Banks}

The complexity of financial system structures has introduced new challenges for central banks in the area of assessing systemic risk and shaping global financial stability. The complex and uncertainty-driven nature of the recent financial crisis has revealed imperfections of knowledge on the part of regulators, including central banks. This imperfect knowledge relates to causality on global financial markets. Using Kuhn's language, the economists have been able to identify the effects of events that caused the financial crisis. However, they are struggling to explain its causes. Thus, the financial crisis is also a crisis of cognition, as evidenced by the limited ability financial market participants had in perceiving risk, while regulatory institutions were facing obstacles in shaping market behaviour. In this context, a consistent policy of equipping contemporary central banks with macro-prudential policy tools could be an important change.

Keywords: monetary policy, financial crisis, macroprudential regulation, complexity. 